\title{
Glycollate Metabolism in the Obligate Chemolithotroph Thiobacillus neapolitanus Grown in Continuous Culture
}

\author{
By R. F. BEUDEKER, ${ }^{1 *}$ J. G. KUENEN ${ }^{1}+$ AND G. A. CODD ${ }^{2}$ \\ ${ }^{1}$ Department of Microbiology, University of Groningen, Kerklaan 30, 9751 NN Haren, \\ The Netherlands \\ ${ }^{2}$ Department of Biological Sciences, University of Dundee, Dundee DD1 4HN, U.K.
}

(Received 9 February 1981; revised 27 March 1981)

$\mathrm{CO}_{2}$-limited chemostat cultures of Thiobacillus neapolitanus excreted $13.5 \mathrm{nmol}$ glycollate $\min ^{-1}$ (mg protein $)^{-1}$. This confirmed the earlier finding that glycollate excretion by $T$. neapolitanus is dependent on the $\mathrm{CO}_{2} / \mathrm{O}_{2}$ ratio applied in the chemostat and thus is probably due to the oxygenase activity of D-ribulose-1,5-bisphosphate (RuBP) carboxylase. RuBPdependent oxygen uptake and activity of phosphoglycollate phosphatase were demonstrated in cell-free extracts of $T$. neapolitanus.

Thiobacillus neapolitanus was able to metabolize exogenous glycollate only to a limited extent. The proportion of dry weight that was derived from $\left[1-{ }^{14} \mathrm{C}\right]$ glycollate by both $\mathrm{CO}_{2}$ and thiosulphate-limited chemostat cultures was only $0.7 \%$ of the total. Short-term labelling experiments with $\left[1-{ }^{14} \mathrm{C}\right]$ glycollate and enzyme studies indicated that $T$. neapolitanus can metabolize glycollate via two pathways. The enzymes of the glycine-serine pathway were demonstrated in cell-free extracts, but on the basis of kinetic experiments it was concluded that this pathway does not play a major role in glycollate metabolism. Malate was the major primary labelling product. Glyoxylate, formed from glycollate, may be incorporated into malate via malate synthase, which was detected in cell-free extracts of $T$. neapolitanus.

The activities of the enzymes needed for the metabolism of glycollate were independent of growth conditions applied in the chemostat. The results are discussed in relation to the possible causes of obligate chemolithotrophy.

\section{INTRODUCTION}

It is generally accepted that glycollate production by autotrophs is principally due to the oxygenase activity of D-ribulose-1,5-bisphosphate carboxylase (RuBP oxygenase) (for reviews, see Jensen \& Bahr, 1977; Chollet, 1977; Beck, 1979). Glycollate is often found as an excretion product not only of photoautotrophs but also of some chemolitho(auto)trophs. The hydrogen-oxidizing bacterium Alcaligenes eutrophus excreted glycollate during $\mathrm{H}_{2}$ oxidation (Codd et al., 1976) and glycollate excretion by the obligate chemolithotroph Thiobacillus neapolitanus was found during growth in a thiosulphate-limited chemostat at various dilution rates (Cohen et al., 1979). Glycollate excretion rates increased with decreasing ratios of supplied $\mathrm{CO}_{2} / \mathrm{O}_{2}$, indicating that glycollate production by $T$. neapolitanus was also due to the RuBP oxygenase activity. The reason why glycollate is excreted by this organism rather than metabolized is unknown. In the course of our studies it became clear that $T$. neapolitanus was able to metabolize glycollate to a limited extent. The possibility of a metabolic bottleneck for glycollate metabolism was investigated by studying glycollate metabolism by $T$. neapolitanus in detail.

† Present address: Department of Microbiology. Delft University of Technology, Julianalaan 67A, 2628 BC Delft, The Netherlands. 


\section{METHODS}

Organism and growth conditions. Thiobacillus neapolitanus strain $\mathrm{X}$ was grown at $28^{\circ} \mathrm{C}, \mathrm{pH} 6.8$, in a chemostat under thiosulphate and $\mathrm{CO}_{2}$ limitation as described previously (Beudeker et al., 1980). The dilution rate (D) was $0.07 \mathrm{~h}^{-1}$ and the dissolved oxygen concentration was $50 \%$ of the air saturation value. Details of the operation of the chemostat were described by Kuenen \& Veldkamp (1973). The basal growth medium contained $(\%, w / v): \mathrm{NH}_{4} \mathrm{Cl}, 0.04 ; \mathrm{MgSO}_{4} .7 \mathrm{H}_{2} \mathrm{O}, 0.08 ; \mathrm{KH}_{2} \mathrm{PO}_{4}, 0.05 ; \mathrm{K}_{2} \mathrm{HPO}_{4}, 0.05 ; \mathrm{Na}_{2} \mathrm{~S}_{2} \mathrm{O}_{3} .5 \mathrm{H}_{2} \mathrm{O}, 1.0$. Two ml of trace element mixture (Vishniac \& Santer, 1957) were added to 11 of medium. $\mathrm{NH}_{4}^{+}$limitation was achieved by using a 10-fold lower concentration of $\mathrm{NH}_{4} \mathrm{Cl}$ in the basal medium $(0.004 \%)$. During this growth mode $1 \mathrm{M}-\mathrm{Na}_{2} \mathrm{CO}_{3}$ was used for $\mathrm{pH}$ control.

Short-term ${ }^{14} \mathrm{C}$-labelling experiments were performed with cells grown in the chemostat under similar conditions, but without aeration control. Care was taken, however, to ensure that oxygen was not growth-limiting. All other experiments described were carried out on samples taken from steady-state cultures.

Experiments with $\left[1-{ }^{14} \mathrm{C}\right]$ glycollate. Measurements of the incorporation of ${ }^{14} \mathrm{C}$ from $\left[1-{ }^{14} \mathrm{C}\right]$ glycollate by chemostat-grown cultures of $T$. neapolitanus into high molecular weight material $(0.25 \mathrm{M}$-perchloric acid precipitable) were performed essentially as described for the incorporation of $\left[2-{ }^{14} \mathrm{C}\right]$ acetate into this organism by Kuenen \& Veldkamp (1973). $\left[1{ }^{14} \mathrm{C}\right]$ Glycollate was sterilized separately through a membrane filter of $0.2 \mu \mathrm{m}$ pore size (Sartorius). The concentration of $\left[1-{ }^{14} \mathrm{C}\right]$ glycollate in the growth medium was $2 \mathrm{~mm}$ with a specific radioactivity of $12.5 \mu \mathrm{Ci} \mathrm{mmol}{ }^{-1}\left(0.46 \mathrm{MBq} \mathrm{mmol}^{-1}\right)$.

For short-term labelling experiments $\left[1-{ }^{14} \mathrm{C}\right]$ glycollate was purified by paper chromatography (Long et al., 1951). The kinetics of $\left[1-{ }^{14} \mathrm{C}\right]$ glycollate assimilation were determined using thiosulphate- and $\mathrm{NH}_{4}^{+}$-limited cells taken from the chemostat. A $20 \mathrm{ml}$ sample $\left(3.2 \mathrm{mg}\right.$ dry $\left.w \mathrm{wl}^{-1}\right)$ of washed cells was suspended in fresh growth medium. After $5 \mathrm{~min}$ aeration and equilibration at room temperature, $72 \mu \mathrm{g}$ sodium glycollate was added, this being the amount calculated to be used by the cells during $5 \mathrm{~min}$. After another $5 \mathrm{~min}, 100 \mu \mathrm{mol}$ glycollate, containing $31.4 \mu \mathrm{Ci}\left[1{ }^{14} \mathrm{C}\right]$ glycollate in $1.6 \mathrm{ml}$, were added, and $2 \mathrm{ml}$ samples were then removed at short intervals into $8 \mathrm{ml}$ ethanol, which killed the organisms instantly.

The samples were extracted overnight at room temperature. After centrifugation the pellets were washed twice with $50 \%(\mathrm{v} / \mathrm{v})$ ethanol and the combined supernatants were rotary evaporated at $35^{\circ} \mathrm{C}$. Portions of about $100 \mu \mathrm{l}$ of these concentrated samples were placed on cellulose thin-layer plates (Merck). The plates were sprayed with pyridine buffer (pyridine/acetic acid/water, 1:7:92, by vol.; $\mathrm{pH} 4$ ) and placed in a Pherograph high-voltage electrophoresis apparatus. The samples were separated for $80 \mathrm{~min}$ at $1000 \mathrm{~V}$ in pyridine buffer. After drying the plates overnight separation was effected in a second dimension by thin-layer chromatography (t.l.c.) in a mixture of 2-butanol/formic acid/water $(6: 1: 2$, by vol.) until the front was $10 \mathrm{~cm}$ from the origin. The plates were dried for $2 \mathrm{~h}$ and the t.l.c. was repeated until the front was within $4 \mathrm{~cm}$ of the top.

Before the plates were overlaid with $\mathrm{X}$-ray film the very active spot of unused $\left[{ }^{14} \mathrm{C} /\right.$ glycollate was scraped off. The plates were kept on X-ray film for 4 weeks and the location and identification of the products were performed according to Schürman (1969). Radioactivity in the spots was determined by standard scintillation counting after scraping the material from the plates.

Enzymes. Cell-free extracts were made according to Kuenen \& Veldkamp (1973) using the buffer appropriate to the particular enzyme assay. Dithiothreitol (DTT) was always added to the buffers at a concentration of $1 \mathrm{~mm}$.

Assays for glyoxylate-glutamate aminotransferase (glycine aminotransferase; EC 2.6.1.4), serine transhydroxymethylase (EC 2.1.2.1), glycerate kinase (EC 2.7.1.31) glyoxylate carboligase (tartronic semialdehyde synthase; EC 4.1.1.47), tartronic semialdehyde reductase (EC 1.1.1.60), hydroxypyruvate reductase (EC 1.1.1.81) and the formation of glycerate from serine were carried out according to Codd \& Stewart (1973). The enzymic tautomerization of tartronic semialdehyde to hydroxypyruvate was tested by the method of Braun \& Kaltwasser (1979). Glycollate dehydrogenase activity was measured as glyoxylate formation by the phenylhydrazine procedure of Codd \& Schmid (1972). Anaerobic glycollate-dependent 2,6-dichlorophenolindophenol (DCPIP) reduction (e.g. Codd \& Stewart, 1973) was not detected.

The phosphoenolpyruvate (PEP) carboxylase (EC 4.1.1.31), PEP carboxykinase (EC 4.1.1.32) and pyruvate carboxylase (EC 6.4.1.1) were assayed according to Sahl \& Trüper (1977). The effect of acetyl CoA was tested by adding $10 \mu \mathrm{l}$ acetyl $\mathrm{CoA}\left(10 \mu \mathrm{mol} \mathrm{ml} \mathrm{m}^{-1}\right)$ to the reaction mixture. The activities were expressed in terms of phosphoenolpyruvate- and pyruvate-dependent $\mathrm{CO}_{2}$ fixation. Rates of $\mathrm{CO}_{2}$ fixation were always linear with time.

The oxygenase activity of D-ribulose-1,5-bisphosphate carboxylase (RuBP oxygenase) (EC 4.1.1.39) was assayed following the procedure of Lorimer et al. (1977). The amount of $\mathrm{CO}_{2}$ in the reaction mixture was determined in the inorganic channel of a total organic carbon analyser (Beckman). A $K_{\mathrm{i}}\left(\mathrm{CO}_{2}\right)$ of $17 \mu \mathrm{M}$ was assumed (Jensen \& Bahr, 1977).

Phosphoglycollate phosphatase (EC 3.1.3.18) was assayed according to Codd et al. (1976), and glyoxylate reductase (EC 1.1.1.26) activity according to Saxena \& Vishniac (1970).

Malate synthase (EC 4.1.3.2) was assayed in a $1 \mathrm{ml}$ reaction mixture containing $10 \mathrm{~mm}$ - $\mathrm{Tris} / \mathrm{HCl}(\mathrm{pH} 8 \cdot 0)$, $0.2 \mathrm{~mm}$-5,5'-dithiobis(2-nitrobenzoic acid) in $10 \mathrm{~mm}$-Tris/ $\mathrm{HCl}$ (pH 8.0) $0.012 \mathrm{~mm}$-acetyl CoA, $10 \mathrm{~mm}^{-} \mathrm{MgCl}_{2}$, $4 \mathrm{~mm}$-glyoxylate, and cell-free extract (up to $2 \mathrm{mg}$ protein). The glyoxylate-dependent increase in $A_{412}$ was taken as 
a measure of activity $\left(\varepsilon_{412} 13.61 \mathrm{mmol}^{-1} \mathrm{~cm}^{-1}\right)$. Details were obtained from Dr M. M. Attwood (personal communication).

Alanine dehydrogenase (EC 1.4.1.1) aminating activity was determined following the procedure of Rowell \& Stewart (1976).

Protein determination. Protein in cell-free extracts was determined by the method of Lowry, using bovine serum albumin as a standard with appropriate corrections for Tris and DTT when these were present in buffers. The method of Bradford (1976) gave virtually the same results as the Lowry method and was used in the later studies with extracts containing compounds which interfere in the Lowry method.

Contamination with other bacteria. Cultures were frequently checked for contaminants as described by Kuenen \& Veldkamp (1973).

Glycollate determination. Various compounds interfered with the Calkins method for the determination of glycollate (Lewis \& Weinhouse, 1957) and a gas-chromatographic procedure was used instead (obtained from $\mathrm{Dr}$ M. Blaauwboer). Supernatant liquids $(500 \mathrm{ml})$ of steady-state cultures were filtered through a G5 glass filter (1.0-1.7 $\mu \mathrm{m}$ pore size; Schott \& Gen, Mainz, F.R.G.). Salts were removed by passing the filtered supernatant liquid through an Amberlite IR-120 column ( $\mathrm{H}^{+}$form) and subsequently through an Amberlite IRA-440-8 column $\left(\mathrm{OH}^{-}\right.$form), from which the organic acids were obtained by elution with $1 \mathrm{M}-\mathrm{HCl}$. The eluate was brought to $\mathrm{pH} 13$ with $\mathrm{NaOH}$ and then freeze-dried. The lyophilized residue was propylated by adding $0.2 \mathrm{ml}$ propanol saturated with gaseous $\mathrm{HCl}$ and $0.8 \mathrm{ml}$ pentane. This mixture was heated for $20 \mathrm{~min}$ at $100{ }^{\circ} \mathrm{C}$ in a closed screw-cap tube. After cooling, $1 \mathrm{ml}$ saturated $\left(\mathrm{NH}_{4}\right)_{2} \mathrm{SO}_{4}$ was added to the propylated mixture. The pentane fraction (upper layer) was dried with $\mathrm{Na}_{2} \mathrm{SO}_{4}$ (stored at $105^{\circ} \mathrm{C}$ ). The dry pentane fractions were kept at $-20^{\circ} \mathrm{C}$.

The propylated organic acids were determined by gas-liquid chromatography using a Packard Becker 421 gas chromatograph with a flame ionization detector equipped with temperature programming. A glass column packed with $5 \%$ diethylglycoladipate (DEGA) on $80-100$ mesh Chromosorb W-AW incorporated with $0.5 \% \mathrm{H}_{3} \mathrm{PO}_{4}$ was used as a stationary phase. The column was left overnight at $200^{\circ} \mathrm{C}$ before use. The injection volume was $9 \mu$ l. Initially the column was kept at $70^{\circ} \mathrm{C}$ for $2 \mathrm{~min}$, after which the temperature was increased to $190{ }^{\circ} \mathrm{C}$ at a rate of $5{ }^{\circ} \mathrm{C} \mathrm{min}^{-1}$, and maintained at this temperature for $2 \mathrm{~min}$. The oven and column were cooled for $10 \mathrm{~min}$ between runs. The temperatures of the injection ports and detection chamber were maintained at $180^{\circ} \mathrm{C}$ and $240^{\circ} \mathrm{C}$, respectively. Nitrogen was passed through the column at a flow rate of $30 \mathrm{ml} \mathrm{min}{ }^{-1}$. Adipic acid was used as an internal standard and was added to the sample to a concentration of $1 \mathrm{~mm}$.

In later experiments glycollate was also detected using glycollate oxidase (Sigma).

Mass spectrometry was carried out using a Sinnigan 3300 mass spectrometer.

Chemicals All radioisotopes were purchased from Amersham. RuBP, phosphoglycollate [tri(cyclohexylammonium) salt], tetrahydrofolate, D-glycerate and hydroxypyruvate were obtained from Sigma. Acetyl CoA was from Fluka, Buchs, Switzerland. Nicotinamide nucleotides, PEP, malate dehydrogenase and pyruvate kinase were bought from Boehringer. DEGA and Chromosorb W-AW came from Chrompack, Middelburg, The Netherlands. All other chemicals were of analytical grade (Merck or BDH).

\section{RES ULTS}

Glycollate production by $T$. neapolitanus was studied in cultures grown in the chemostat at a fixed dilution rate of $0.07 \mathrm{~h}^{-1}$ under thiosulphate or $\mathrm{CO}_{2}$ limitation and at different dissolved oxygen concentrations. Glycollate was the major excretion product under the conditions tested. It was identified and quantified by gas chromatography and subsequent mass spectrometry. The results obtained (Table 1) confirm and extend earlier findings (Cohen et al., 1979) that glycollate excretion is dependent on the $\mathrm{O}_{2} / \mathrm{CO}_{2}$ ratio in the culture. Under $\mathrm{CO}_{2}$ limitation about $27 \%$ of all the carbon fixed was excreted as glycollate. The earlier supposition (Cohen et al., 1979) that glycollate production by $T$. neapolitanus is due to the oxygenase activity of RuBP carboxylase is supported by the fact that RuBP-dependent oxygen uptake as well as phosphoglycollate phosphatase activity could be demonstrated in cell-free extracts (Table 2). It should be noted that an almost constant ratio of RuBP oxygenase to RuBP carboxylase activity was found under the different growth conditions.

The increased RuBP oxygenase activity under $\mathrm{CO}_{2}$ limitation (Table 2) is in agreement with the increased RuBP carboxylase activity under $\mathrm{CO}_{2}$ limitation (Beudeker et al., 1980). The glycollate excretion rate (Table 1) also correlated with the RuBP oxygenase activity. Though phosphoglycollate phosphatase showed lower activity during $\mathrm{CO}_{2}$ limitation, compared with thiosulphate limitation, this activity in vitro was still high enough to account for the glycollate excretion rate during $\mathrm{CO}_{2}$ limitation (Table 1). 
Table 1. Effect of the $\mathrm{O}_{2} / \mathrm{CO}_{2}$ ratio in the chemostat on the rate of excretion of glycollate by Thiobacillus neapolitanus

Cultures were grown at a dilution rate of $0.07 \mathrm{~h}^{-1}$, at $28^{\circ} \mathrm{C}$, pH 6.8 .

\begin{tabular}{|c|c|c|c|c|c|}
\hline $\begin{array}{l}\text { Growth-limiting } \\
\text { substrate }\end{array}$ & $\begin{array}{l}\text { Dissolved } \\
\mathrm{O}_{2} \text { concn } \\
\text { (\% of air } \\
\text { saturation) }\end{array}$ & $\begin{array}{c}\text { Inorganic C } \\
\left(\mathrm{mg} \mathrm{l}^{-1}\right)\end{array}$ & $\begin{array}{c}\text { Organic C } \\
\left(\mathrm{mg} \mathrm{l}^{-1}\right)\end{array}$ & $\begin{array}{c}\text { Glycollate } \\
\text { content of } \\
\text { culture } \\
\left(\mathrm{mg} \mathrm{l}^{-1}\right)\end{array}$ & $\begin{array}{c}\text { Glycollate } \\
\text { excretion rate } \\
{\left[\text { nmol min }{ }^{-1}\right.} \\
\left.(\mathrm{mg} \text { protein })^{-1}\right]\end{array}$ \\
\hline $\begin{array}{l}\text { Thiosulphate } \\
\text { Thiosulphate } \\
\mathrm{CO}_{2}\end{array}$ & $\begin{array}{r}50 \\
5 \\
50\end{array}$ & $\begin{array}{r}6 \\
6 \\
<1\end{array}$ & $\begin{array}{r}2-3 \\
1-2 \\
13\end{array}$ & $\begin{array}{c}4 \cdot 3 \\
\text { ND } \\
28 \cdot 9\end{array}$ & $\begin{array}{c}0.8 \\
\text { ND } \\
13 \cdot 5\end{array}$ \\
\hline
\end{tabular}

Table 2. Oxygenase and carboxylase activity of D-ribulose-1,5-bisphosphate carboxylase and activity of phosphoglycollate phosphatase in extracts of Thiobacillus neapolitanus grown in the chemostat under different nutrient limitations

Cultures were grown at a dilution rate of $0.07 \mathrm{~h}^{-1}$ with a dissolved oxygen concentration of $50 \%$ of air saturation.

\begin{tabular}{|c|c|c|c|c|}
\hline \multirow[b]{2}{*}{$\begin{array}{l}\text { Growth-limiting } \\
\text { substrate }\end{array}$} & \multicolumn{3}{|c|}{ Enzyme activity $\left[\mathrm{nmol} \mathrm{min}^{-1}(\mathrm{mg} \text { protein })^{-1}\right]$} & \multirow{2}{*}{$\begin{array}{l}\text { Ratio RuBP oxygenase } \\
\text { activity/RuBP carboxylase } \\
\text { activity (\%) }\end{array}$} \\
\hline & $\begin{array}{c}\text { RuBP } \\
\text { oxygenase }\end{array}$ & $\begin{array}{c}\text { RuBP } \\
\text { carboxylase }\end{array}$ & $\begin{array}{c}\text { Phosphoglycollate } \\
\text { phosphatase }\end{array}$ & \\
\hline $\begin{array}{l}\text { Thiosulphate } \\
\mathrm{CO}_{2} \\
\text { Thiosulphate } \\
{\left[+5 \%(\mathrm{v} / \mathrm{v}) \mathrm{CO}_{2} \text { in the }\right.} \\
\text { gas phase }]\end{array}$ & $\begin{array}{l}20 \\
80 \\
16\end{array}$ & $\begin{array}{r}72 \\
240 \\
45\end{array}$ & $\begin{array}{l}41 \\
17 \\
57\end{array}$ & $\begin{array}{l}28 \\
33 \\
35\end{array}$ \\
\hline
\end{tabular}

To investigate whether T. neapolitanus was able to metabolize glycollate, the incorporation of $\left[1-{ }^{14} \mathrm{C}\right]$ glycollate into high molecular weight material was measured in continuous culture. The contribution of $\left[1-{ }^{14} \mathrm{C}\right]$ glycollate to total cell carbon was $1.5 \%$ during steady state conditions, assuming that the carbon content was $50 \%$, and the protein content of the cells was $60 \%$ of the dry weight, respectively (Kuenen, 1979). Under $\mathrm{CO}_{2}$ limitation, during which the glycollate excretion rate was much higher than under thiosulphate limitation (Table 1), virtually the same level of incorporation of glycollate into high molecular weight material was observed. Both $\mathrm{CO}_{2}$ - and thiosulphate-limited cells incorporated $0.7 \mathrm{nmol}$ glycollate $\mathrm{min}^{-1}$ (mg protein $)^{-1}$. The glycollate incorporation rate into high molecular weight material was calculated from the growth rate (= dilution rate) and the protein content of the culture.

The limited metabolism of glycollate by $T$. neapolitanus might be due to insufficient activities of enzymes of glycollate metabolism. To investigate this possibility the metabolic pathway for glycollate was examined by short-term labelling experiments, and assays for the relevant enzymes. Short-term labelling experiments were carried out with steady-state cells from both $\mathrm{NH}_{4}^{+}$and thiosulphate-limited cultures. It should be noted that during $\mathrm{NH}_{4}^{+}$ limitation glycollate was not excreted by $T$. neapolitanus $\left(D=0.07 \mathrm{~h}^{-1}\right.$; dissolved oxygen concentration, $50 \%$ of air saturation). The $\left[1-{ }^{14} \mathrm{C}\right]$ glycollate short-term labelling pattern for $\mathrm{NH}_{4}^{+}$-limited cells is shown in Fig. 1. After $7 \mathrm{~s}$ of labelling, malate accounted for the highest percentage of the ${ }^{14} \mathrm{C}$ incorporated $(30 \%$ of the total label on the t.l.c. plate). The kinetics of malate labelling were typical for a primary product. The percentage of label in citrate (+ glycerate) varied between 15 and $32 \%$. The principal labelled amino acids were glutamate and aspartate. Although spots of glycine and serine were easily detectable on the chromatograms by spraying with ninhydrin, no radioactivity was found in these compounds 


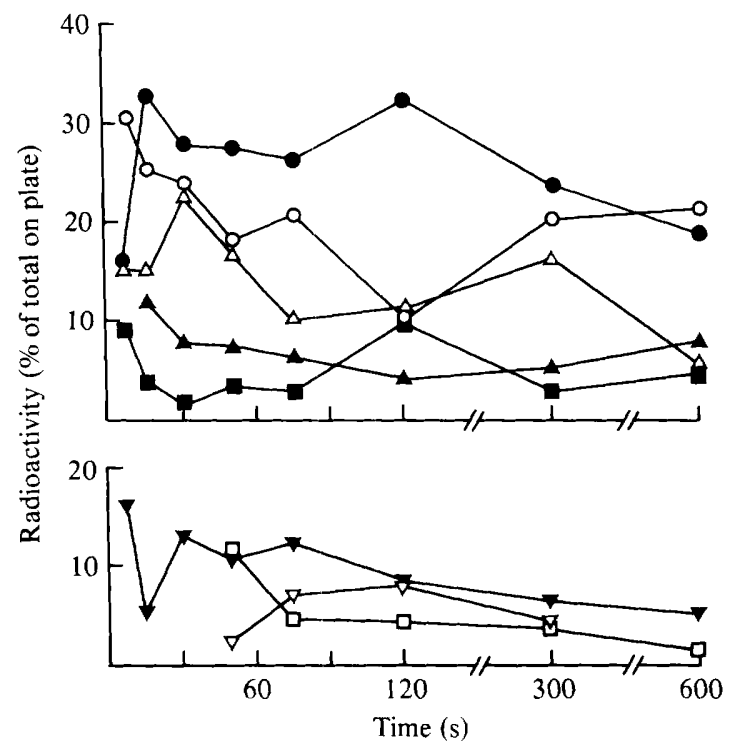

Fig. 1. Short-term kinetics of the incorporation of ${ }^{14} \mathrm{C}$ from $\left[1-{ }^{14} \mathrm{C}\right]$ glycollate into cellular compounds by $\mathrm{NH}_{4}^{+}$-limited cells of Thiobacillus neapolitanus. $\mathrm{O}$, malate; $\mathrm{O}$, citrate (+ glycerate); $\Delta$, sugar monophosphates; $\boldsymbol{\Delta}$, sugar diphosphates; $\mathbf{\square}$, phosphoglycerate; $\square$, glycine + serine; $\boldsymbol{\nabla}$, glutamate; $\nabla$, aspartate.

until after $50 \mathrm{~s}$ of labelling. Phosphoglycerate and sugar phosphates were also among the early labelling products. Trace amounts of ${ }^{14} \mathrm{C}$ were detected in PEP, alanine and sucrose (results not shown). The kinetics of $\left[1{ }^{14} \mathrm{C} / \mathrm{gly}\right.$ collate assimilation by thiosulphate-limited cells were very similar to those of $\mathrm{NH}_{4}^{+}$-limited cells (results not shown). Malate and citrate (+ glycerate) were the major early labelling products. In contrast to $\mathrm{NH}_{4}^{+}$-limited cells, alanine was the principal amino acid labelled in thiosulphate-limited cells. Some radioactivity could be detected in serine and glycine; after $10 \mathrm{~s}$ of labelling these amino acids together accounted for $6 \%$ of the label found on the chromatogram but in later samples no label could be found in these compounds.

Following the short-term labelling experiments, enzyme studies were carried out with extracts from thiosulphate- and $\mathrm{NH}_{4}^{+}$-limited cultures to obtain further information on possible routes of glycollate metabolism, including the glycine-serine pathway and the glycerate pathway to tartronic semialdehyde (Table 3). Cell-free $T$. neapolitanus extracts catalysed the oxidation of glycollate to glyoxylate. The activity of the glycollate-oxidizing enzyme was identical with D-lactate or glycollate as a substrate. With L-lactate as a substrate no activity could be observed. Cyanide $(1 \mathrm{~mm})$ inhibited the enzyme activity completely. According to Tolbert (1976) the glycollate-oxidizing enzyme of $T$. neapolitanus can thus be termed a glycollate dehydrogenase. Glyoxylate reductase activity was readily detectable in cell-free extract of $T$. neapolitanus (Table 3 ).

Maximal rates of glycine formation from glyoxylate were found in the presence of fresh cell extracts plus glutamate as amino donor (Table 4). Alanine was also effective. Although the presence of cell extract was required for high activity, boiling the extract for $10 \mathrm{~min}$ had little inhibitory effect (Table 4). The net fresh extract plus glutamate-dependent reaction rates for glyoxylate transamination are given in Table 3. Maximum glycine-serine interconversion rates with extracts of thiosulphate-limited cells were obtained with addition of pyridoxal phosphate and tetrahydrofolate. Extracts of $\mathrm{NH}_{4}^{+}$-limited cells showed comparable results (Table 3). The deamination of serine to hydroxypyruvate followed by reduction to glycerate consistently showed very low activity (Table 3 ) whilst the reduction of hydroxypyruvate to 
Table 3. Activities of enzymes of glycollate metabolism and related reactions in extracts of Thiobacillus neapolitanus grown in the chemostat under thiosulphate and under $\mathrm{NH}_{4}^{+}$limitation

Cultures were grown at a dilution rate of $0.07 \mathrm{~h}^{-1}$ with a dissolved oxygen concentration of $50 \%$ of air saturation. The numbers in parentheses refer to Fig. 2.

Enzyme or reaction $\overbrace{\begin{array}{c}\text { Growth-limiting substrate } \\ \text { Thiosulphate } \quad \mathrm{NH}_{4}^{+}\end{array}}^{\text {Activity }\left[\mathrm{nmol} \mathrm{min}{ }^{-1}(\mathrm{mg} \text { protein })^{-1}\right]}$

$\begin{array}{lcc}\text { Glycollate dehydrogenase (3) } & 0.2 & 0 \cdot 2 \\ \text { Glyoxylate reductase (4) } & 20 & 25 \\ \text { Glyoxylate aminotransferase (5) } & 0 \cdot 8 & 0 \cdot 8 \\ \text { Serine transhydroxymethylase (6) } & 3 \cdot 8 & 2 \cdot 2 \\ \text { Conversion of serine to glycerate (7) } & 0 \cdot 2 & 0 \cdot 3 \\ \text { Hydroxypyruvate reductase (8) } & 7 & 8 \\ \text { Glycerate kinase (9) } & 0.5 & 0 \cdot 5 \\ \text { Glyoxylate carboligase (10) } & \text { ND } & \text { ND } \\ \text { Tartronic semialdehyde reductase (11) } & \text { ND } & \text { NM } \\ \text { Tautomerization of TSA to hydroxypyruvate (12) } & \text { ND } & \text { NM } \\ \text { Malate synthase (13) } & 0 \cdot 7 & 0.7 \\ \text { Phosphoenolpyruvate carboxylase (14) } & 21 & 24^{*} \\ \text { Phosphoenolpyruvate carboxylase + ADP (14) } & 43 & 45^{*} \\ \text { Pyruvate carboxylase (15) } & 1 & 0.8 \\ \text { Alanine dehydrogenase (16) } & 21 & \text { ND }\end{array}$

$\mathrm{ND}$, No detectable activity, using up to $2 \mathrm{mg}$ protein in the assay. NM, Not measured.

* In the presence of acetyl CoA.

Table 4. Formation of $\left[{ }^{14} \mathrm{C}\right]$ glycine from $\left[1-{ }^{14} \mathrm{C}\right]$ glyoxylate (glyoxylate aminotransferase) by extracts of Thiobacillus neapolitanus grown under $\mathrm{NH}_{4}^{+}$limitation in the chemostat

Cultures were grown at a dilution rate of $0.07 \mathrm{~h}^{-1}$ with a dissolved oxygen concentration of $50 \%$ of air saturation.

$\begin{array}{lcc}\text { Assay condition } & \begin{array}{c}{ }^{14} \mathrm{C} \text { in glycine } \\ \text { (d.p.m.) }\end{array} & \begin{array}{c}\text { Relative rate (\% of } \\ \text { max. enzyme activity) }\end{array} \\ \text { No enzyme + L-glutamate } & 454 & 21 \\ \text { Boiled enzyme + L-glutamate } & 1858 & 87 \\ \text { Enzyme + L-glutamate } & 2142 & 100^{*} \\ \text { Enzyme + DL-alanine } & 1998 & 93 \\ \text { Enzyme without amino donor } & 266 & 12\end{array}$

* See Table 3 for the absolute activity.

glycerate was easily detectable. It should be noted that hydroxypyruvate reduction can be catalysed by glyoxylate reductase (Bamforth \& Quayle, 1977). Extracts of T. neapolitanus were also able to convert glycerate into pyruvate when ATP, $\mathrm{Mg}^{2+}, \mathrm{PEP}$ and pyruvate kinase were added to the assay system, which is an indication of glycerate kinase activity. These data indicated that $T$. neapolitanus extracts were able to convert glycollate to phosphoglycerate via the glycine-serine pathway. If, however, this pathway had been the major pathway of glycollate metabolism, then the percentage of label in glycine and serine would have exceeded that in malate at the shortest time interval. This was not observed with either $\mathrm{NH}_{4}^{+}$-limited or thiosulphate-limited cells (see Fig. 1).

An alternative way to metabolize glyoxylate is via the so-called glycerate pathway which has been shown to be operative, for example, in Thiobacillus novellus (Chandra \& Shethna, 1977) and Anabaena cylindrica (Codd \& Stewart, 1973). In this pathway two molecules of glyoxylate are condensed to tartronic semialdehyde (TSA) and $\mathrm{CO}_{2}$ by glyoxylate 
carboligase. The semialdehyde is further reduced to glycerate by TSA reductase. Extracts of $T$. neapolitanus from $\mathrm{NH}_{4}^{+}$- and thiosulphate-limited cultures were repeatedly assayed for glyoxylate carboligase activity, but did not show any enzymic glyoxylate decarboxylation activity under anaerobic conditions (though $\left[1-{ }^{14} \mathrm{C}\right]$ glyoxylate was decarboxylated to a very limited extent by chemical conversion). The reaction product tartronic semialdehyde could not be detected during this assay but was easily detected when the assay was performed using cell-free extracts of glycollate-grown Escherichia coli. Braun \& Kaltwasser (1979) have reported the enzymic tautomerization of TSA to hydroxypyruvate in Bacillus fastidiosus. Such an enzyme reaction could not be detected in cell free extracts of $T$. neapolitanus from $\mathrm{NH}_{4}^{+}$- or thiosulphate-limited cultures. TSA produced in the assay for glyoxylate carboligase by glycollate-grown $E$. coli could not be reduced to glycerate by cell free extracts of $T$. neapolitanus (Table 3).

Enzymic evidence for the metabolism of glyoxylate to malate (see Fig. 1) was sought. Though the obligate chemolithotroph $T$. neapolitanus does not possess an active glyoxylate cycle (Kelly, 1971) activity of malate synthase could be detected in terms of the glyoxylate-dependent formation of $\mathrm{CoA}$ from acetyl CoA, measured colorimetrically with 5,5'-dithiobis (2-nitrobenzoic acid) (Table 3). Kelly (1967) showed that addition of [2${ }^{14} \mathrm{C}$ ]acetate to extracts of $T$. neapolitanus containing glyoxylate, $\mathrm{CoA}$ and ATP resulted in the formation of labelled malate, which is another indication for malate synthase activity in this organism.

The appearance of ${ }^{14} \mathrm{C}$ from $\left[{ }^{14} \mathrm{C}\right]$ glycollate in citric acid cycle and related compounds suggests the possible participation of $\beta$-carboxylating enzymes, and tests were carried out for the presence of PEP carboxylase and pyruvate carboxylase. PEP-dependent $\mathrm{H}^{14} \mathrm{CO}_{3}$ fixation into acid-stable material only showed activity when $\mathrm{NADH}$ and malate dehydrogenase were added to the assay mixture. Acetyl CoA did not stimulate the activity of extracts of thiosulphate-limited cells but did stimulate the enzyme activity of $\mathrm{NH}_{4}^{+}$-limited cells twofold (Table 3). The $K_{\mathrm{m}}$ for the activation of the enzyme by acetyl CoA may be very low, as has been shown for the Thiobacillus thiooxidans enzyme (Hoban \& Lyric, 1975). $\mathrm{NH}_{4}^{+}$-limited cells probably contain less acetyl CoA (a nitrogen-containing compound) than thiosulphatelimited cells. As the assay was carried out on crude extracts which had not been dialysed, this could explain the lack of stimulation of PEP carboxylase activity in thiosulphate-limited cells. Addition of ADP to the assay mixture increased the PEP-dependent $\mathrm{H}^{14} \mathrm{CO}_{3}$ fixation rate about twofold indicating the activity of a PEP carboxykinase in extracts of $T$. neapolitanus (Table 3). Pyruvate-dependent $\mathrm{H}^{14} \mathrm{CO}_{3}$ fixation into acid-stable material could also be detected in extracts of T. neapolitanus (Table 3).

\section{DISCUSSION}

The possible pathways of glycollate metabolism by $T$. neapolitanus are summarized in Fig. 2. Our results clearly indicate that glycollate is rapidly metabolized via glyoxylate to malate and further into citric acid cycle products. Alanine, the main amino acid labelling product in thiosulphate-limited cells, may have become radioactive by amination of pyruvate which in turn may have been formed from malate by malic enzyme (Johnson \& Abraham, 1969). High alanine dehydrogenase activity was detected in cell-free extracts of thiosulphate-limited cells (Table 3), but this enzyme was undetectable using $\mathrm{NH}_{4}^{+}$-limited cells. This seems to rule out both the serine pathway and the $\beta$-hydroxyaspartate pathway (Kornberg \& Morris, 1963), as important routes for glycollate metabolism in $T$. neapolitanus. The glycine-serine pathway plays an important role in the metabolism of glycollate in higher plants and algae (see Tolbert, 1979). Low activities of some enzymes of the glycine-serine pathway have also been detected in Methylococcus capsulatus (Bath) which has been explained by suggesting an important role of this pathway in the recycling of phosphoglycollate formed by RuBP 


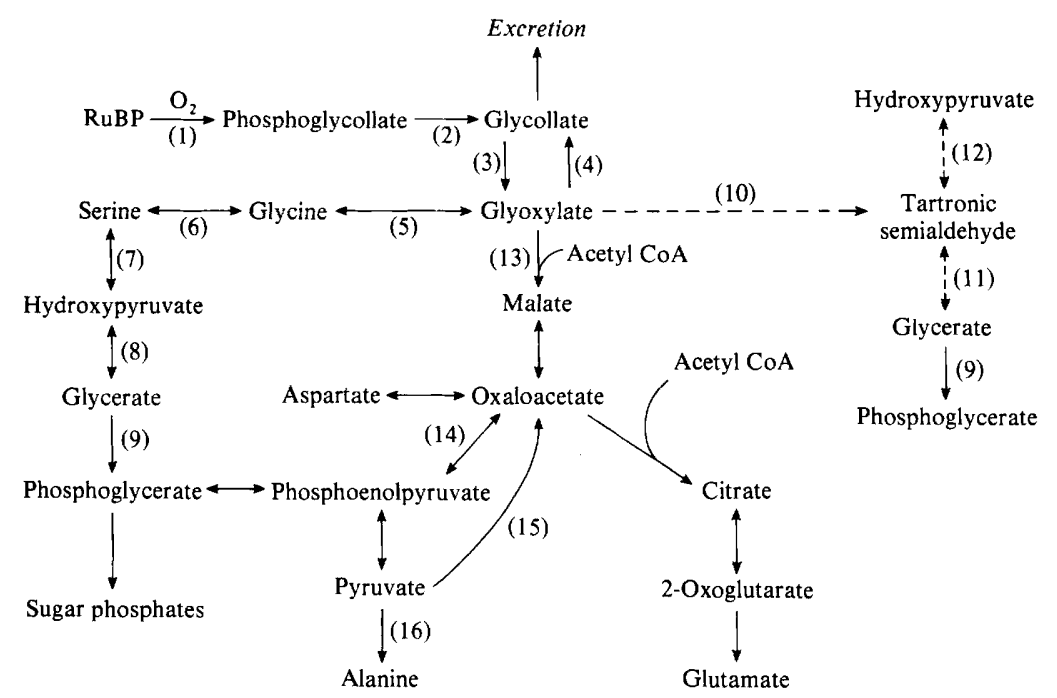

Fig. 2. Possible pathways of glycollate metabolism by Thiobacillus neapolitanus. Numbers in parentheses refer to enzymes assayed in cell-free extracts and listed in Tables 2 and 4. Dashed lines indicate that there is no enzymic evidence for the occurrence of this reaction in T. neapolitanus.

oxygenase (Colby et al., 1979; Taylor et al., 1981). However, the possibility remains that in $T$. neapolitanus the enzymes of this pathway may have another function.

There appears to be no correlation between the applied growth limitation and activities of enzymes involved in glycollate metabolism, though glycollate is excreted during thiosulphate limitation, whereas it is not during $\mathrm{NH}_{4}^{+}$-limitation. These usually identical enzyme activities during different growth conditions (with different glycollate excretion rates) indicate the inability of the organism to increase enzyme activities needed for the metabolism of glycollate. This becomes even more clear when the glycollate incorporation rates are taken in account. During $\mathrm{CO}_{2}$ limitation (when glycollate excretion is high; Table 1) the glycollate incorporation rate is very similar to that during thiosulphate limitation (when the glycollate excretion rate is low).

This study of glycollate metabolism in the obligate chemolithotroph $T$. neapolitanus is particularly interesting in the light of theories concerning the causes of obligate chemolithotrophy. Organisms like T. neapolitanus use $\mathrm{CO}_{2}$ as the major carbon source under normal growth conditions and possess only a very limited ability to assimilate organic compounds (Kelly, 1971; Kuenen \& Veldkamp, 1973). A generally observed phenomenon is that in these organisms, in contrast to facultative chemolithotrophs, activities of enzymes of pathways available for the metabolism of exogenous organic compounds are never induced in response to the presence of the substrate in the medium. This limited ability to metabolize organic compounds has often been attributed to limited transport capacity of the membrane for organic compounds (Rittenberg, 1969; Kelly, 1971; Smith \& Hoare, 1977; Matin, 1978). A consequence of this hypothesis would be that intracellular concentrations of organic substrates might not become high enough to induce enzymes for their own metabolism. If this were true one would expect that enzymes for the metabolism of glycollate which are present at very low activity in T. neapolitanus would be induced under conditions of high intracellular glycollate production. As shown above this appeared not to be the case.

Glycollate metabolism by $T$. neapolitanus results in labelling of several important biosynthetic intermediates (Fig. 1) and thus may be able to substitute for $\mathrm{CO}_{2}$ as a principal carbon source. However, since the thiobacilli occur predominantly at the interface of oxygen and reduced sulphur compounds, glycollate formation, a process favoured by high oxygen tensions, will only occur to a limited extent. Glycollate excretion cannot be detected at low oxygen tensions (Table 1). It seems reasonable to assume that under the normal natural 
conditions for this type of organism the capacity for glycollate incorporation is sufficient to prevent excretion and that the maintenance of genetic and biosynthetic controls on the regulation of the glycollate pathway may consume more energy than the temporary loss of organic carbon.

Glycollate excretion does not take place in $\mathrm{NH}_{4}^{+}$-limited $T$. neapolitanus cultures. Under these growth conditions the rate of respiration per unit dry weight is $20 \%$ higher than in thiosulphate-limited cells. It is possible that the intracellular dissolved oxygen concentration is lower in $\mathrm{NH}_{4}^{+}$, than in thiosulphate-limited cells. The respiration of thiosulphate may, in this way, provide a mechanism to keep a low intracellular oxygen concentration, which could result in a reduction of RuBP oxygenase activity compared with RuBP carboxylase activity. This would explain why glycollate has not been found in $\mathrm{NH}_{4}^{+}$-limited cells. This mechanism for reducing the internal oxygen concentration by respiration is known for Azotobacter species (Postgate, 1974).

The investigations were supported in part by the Foundation for Fundamental Biological Research (BION) which is subsidized by the Netherlands Organization for the Advancement of Pure Research (ZWO).

G. A. C. thanks the Royal Society for a travel grant.

We also thank Drs M. Blaauwboer, M. M. Attwood, C. van der Drift and J. P. van Dijken for helpful advice and Mr K. Hovius for technical assistance, and gratefully acknowledge the help of Dr Bruins (Department of Pharmacy, University of Groningen) in the performance of the mass spectrometric analysis.

\section{REFERENCES}

BAMFORTH, C. W. \& QUAYLE, J. R. (1977). Hydroxypyruvate reductase activity in Paracoccus denitrificans. Journal of General Microbiology 101, 259267.

BECK, E. (1979). Glycolate synthesis. In Photosynthesis II (Encyclopedia of Plant Physiology, New Series, vol. 6), pp. 327-335. Edited by A. Pirson \& M. H. Zimmerman. Berlin: Springer Verlag.

Beudeker, R. F., Cannon, G. C., Kuenen, J. G. \& ShIVEly, J. M. (1980). Relations between Dribulose-1,5-bisphosphate carboxylase, carboxysomes and $\mathrm{CO}_{2}$-fixing capacity in the obligate chemolithotroph Thiobacillus neapolitanus grown under different limitations in the chemostat. Archives of Microbiology 124, 185-191.

BRADFORD, M. (1976). A rapid and sensitive method for the quantitation of microgram quantities of protein utilizing the principle of protein-dye binding. Analytical Biochemistry 72, 248--254.

Braun, W. \& Kaltwasser, H. (1979). Untersuchungen zum Glyoxylsäurewechsel von Bacillus fastidiosus Stamm 83. Archives of Microbiology 121, 129-134.

Chandra, T. S. \& Shethna, Y. I. (1977). Oxalate. formate, formamide and methanol metabolism in Thiobacillus novellus. Journal of Bacteriology 131 , 389-398.

Chollet, R. (1977). The biochemistry of photorespiration. Trends in Biochemical Sciences 2. 155-159.

Codd, G. A. \& Schmid, G. H. (1972). Serological characterization of the glycollate oxidizing enzymes from tobacco, Euglena gracilis and a yellow mutant of Chlorella vulgaris. Plant Physiology 50, 769773.

Codd, G. A. \& Stewart, W. D. P. (1973). Pathways of glycollate metabolism in the blue green alga Anabaena cylindrica. Archiv für Mikrobiologie 94. 11-28.
Codd, G. A., Bowien, B. \& Schlegel, H. G. (1976). Glycollate production and excretion by Alcaligenes eutrophus. Archives of Microbiology 110, 167-171.

Cohen, Y., de Jonge, I. \& Kuenen, J. G. (1979). Excretion of glycollate by Thiobacillus neapolitanus in continuous culture. Archives of Microbiology 122, 189-194.

Colby, J., Dalton, H. \& Whittenbury, R. (1979). Biological and biochemical aspects of microbial growth on $\mathrm{C}_{1}$ compounds. Annual Review of Microbiology 33, 481-517.

Hoban, D. J. \& Lyric, R. M. (1975). Phosphoenolpyruvate carboxylase of Thiobacillus thioparus 1. General properties. Canadian Journal of $\mathrm{Bio}^{-}$ chemistry 53, 875-880.

JENSEN, R. G. \& BAHR, J. T. (1977). Ribulose1,5-bisphosphate carboxylase-oxygenase. Annual Review of Plant Physiology 28, 379-400.

JoHnSON, E. J. \& ABRAHAM, S. (1969). Enzymes of intermediary carbohydrate metabolism in the obligate autotrophs Thiobacillus thioparus and Thiobacillus neapolitanus. Journal of Bacteriology 100 , 962-968.

KELLY, D. P. (1967). The incorporation of acetate by the chemoautotroph Thiobacillus neapolitanus strain C. Archiv für Mikrobiologie 58, 99-116.

KELLY, D. P. (1971). Autotrophy: concepts of lithotrophic bacteria and their organic metabolism. Annual Review of Microbiology 25, 177-210.

KorNberG, H. L. \& MORRIS, J. G. (1963). $\beta$ Hydroxyaspartate pathway: a new route for biosynthesis from glyoxylate. Nature, London 197, 456457.

KUENEN, J. G. (1979). Growth yields and maintenance energy requirement in Thiobacillus species under energy limitation. Archives of Microbiology 122 , 183-188.

Kuenen, J. G. \& VeldKamp, H. (1973). Effects of organic compounds on chemostat cultures of Thio- 
microspira pelophila, Thiobacillus thioparus and Thiobacillus neapolitanus. Archiv für Mikrobiologie 94, 173-190.

Lewis, K. F. \& WeINhouse, S. (1957). Determination of glycolic, glyoxylic and oxalic acids. Methods in Enzymology 3, 272-273.

Long, A. G., Quayle, J. R. Stedtman, R. J. (1951). The separation of acids by paper partition chromatography. Journal of the Chemical Society, 2197-2201.

Lorimer, G. H., Badger, M. R. \& Andrews, T. J. (1977). D-Ribulose-1,5-bisphosphate carboxylaseoxygenase. Analytical Biochemistry 78, 66-75.

Matin, A. (1978). Organic nutrition of chemolithotrophic bacteria. Annual Review of Microbiology 32, 433-469.

Postgate, J. (1974). Prerequisites for biological nitrogen fixation in free living heterotrophic bacteria. In The Biology of Nitrogen Fixation, pp. 663-687. Edited by A. Quispel. Amsterdam: Elsevier/North Holland.

RitTEnBERG, S. C. (1969). The roles of exogenous organic matter in the physiology of chemolithotrophic bacteria. Advances in Microbial Physiology 3, 159-196.

Rowell, P. \& Stewart, W. D. P. (1976). Alanine dehydrogenase of the $\mathrm{N}_{2}$-fixing blue-green alga Anabaena cylindrica. Archives of Microbiology 107, 115-124.

SAHL, H. G. \& TRÜPER, H. G. (1977). Enzymes of
$\mathrm{CO}_{2}$ fixation in Chromatiaceae. FEMS Microbiology Letters 2, 129-132.

SaxenA, J. \& Vishniac, W. (1970). Influence of organic acids on the growth of Thiobacillus neapolitanus. Antonie van Leeuwenhoek, 36, 109118.

SchürmanN, P. (1969). Separation of phosphate esters and algal extracts by thin-layer electrophoresis and chromatography. Journal of Chromatography 39. 507-509.

SMith, A. J. \& HoARE, D. S. (1977). Specialist phototrophs, lithotrophs and methylotrophs: a unity among a diversity of prokaryotes? Bacteriological Reviews 41, 419-448.

Taylor, S. C., Dalton, H. \& Dow, S. C. (1981). Ribulose-1,5-bisphosphate carboxylase/oxygenase and carbon assimilation in Methylococcus capsulatus (Bath). Journal of General Microbiology 122, 89-94.

Tolbert, N. E. (1976). Glycollate oxidase and glycollate dehydrogenase in marine algae and plants. Australian Journal of Plant Physiology 3, 129132.

TOLbert, N. E. (1979). Glycollate metabolism by higher plants and algae. In Photosynthesis II (Encyclopedia of Plant Physiology, New Series, vol. 6), pp. 338-351. Edited by A. Pirson \& M. H. Zimmerman. Berlin: Springer Verlag.

Vishniac, W. \& SANTER, M. (1957). The thiobacilli. Bacteriological Reviews 26, 168-175. 